\title{
Using InSAR settlement data in a levee strengthening project for building settlement risk assessment
}

\author{
Rob R. van Buuren ${ }^{1}$, Jacco K. Haasnoot ${ }^{1}$, Michel de Koning ${ }^{1}$, Marco Weijland ${ }^{2}$, and \\ Hans J. W. van Zanten ${ }^{3}$ \\ ${ }^{1}$ CRUX Engineering, Delft, the Netherlands \\ ${ }^{2}$ Hoogheemraadschap van Schieland en de Krimpenerwaard, Rotterdam, the Netherlands \\ ${ }^{3} \mathrm{BWZ}$ Ingenieurs BV, Everdingen, the Netherlands \\ Correspondence: Rob R. van Buuren (vanbuuren@cruxbv.nl)
}

Published: 22 April 2020

\begin{abstract}
For the levee strengthening project Krachtige IJsseldijken Krimpenerwaard (KIJK) a study has been done to examine all buildings along $10 \mathrm{~km}$ of levee. These buildings are an important factor in the design stage, because of its sensitivity to deformations due to the natural compaction of the soft deposits (creep) and the potential effects of the levee strengthening. This paper covers the quantification of building settlement due to natural subsidence using InSAR. Research is performed in the city archives to establish the characteristics of the buildings, such as the foundation type. Although the city archive is well organised, it is not complete. The building data density is substantially improved using InSAR information. This enhanced data set is a key factor in establishing an consistent assessment of the risk of damage for the different levee strengthening alternatives.
\end{abstract}

\section{Introduction}

Since January 2017 the assessment of safety for primary levees in the Netherlands should comply to the WBI2017 (MIM). When a levee does not comply to the WBI2017 a levee strengthening project is initiated by the Water Authority. An important factor in the design process of such a project are the surrounding buildings and structures. Buildings are exposed to natural land subsidence, caused by creep of soft layers, the drying out of peat or oxidation. Changing water levels and loading of the levee might cause additional effects leading to more subsidence and possibly damage the buildings.

This paper covers the assessment of building settlement and the risk assessment of additional settlement for different levee strengthening designs. The case study for this risk assessment was done for levee strengthening project KIJK. The $10 \mathrm{~km}$ long KIJK (Krachtige IJsseldijken Krimpenerwaard) project is located next to the river Hollandse IJssel, in the Krimpenerwaard near Rotterdam, the Netherlands (see Fig. 1). The Krimpenerwaard is an area with soft Holocene deposits with ongoing subsidence. The levee is densely populated with buildings originating from 1650 till present.

The building settlement rate differs for each building depending on the foundation type and -depth, the age and condition of the building. Also, the potential risk of damage for a building due to additional soil displacements, depends on the foundation type and the condition of the building. The objective of this study is to perform a damage risk assessment of all buildings located within $40 \mathrm{~m}$ from the crest of the levee. This study uses InSAR data to determine the building settlement rate and, by combining other data sources, determine the buildings foundation type with certain probability. Using settlement characteristic and the foundation type, the risk of damage can be determined for different preliminary levee strengthening designs (IB KIJK, 2017). This risk of damage is an important factor for choices made in the design process and determining the most favourable design alternative.

\section{Analysis method}

The analysis starts by filtering the InSAR data (Skygeo, 2017) on useful data points that match the buildings. Data 


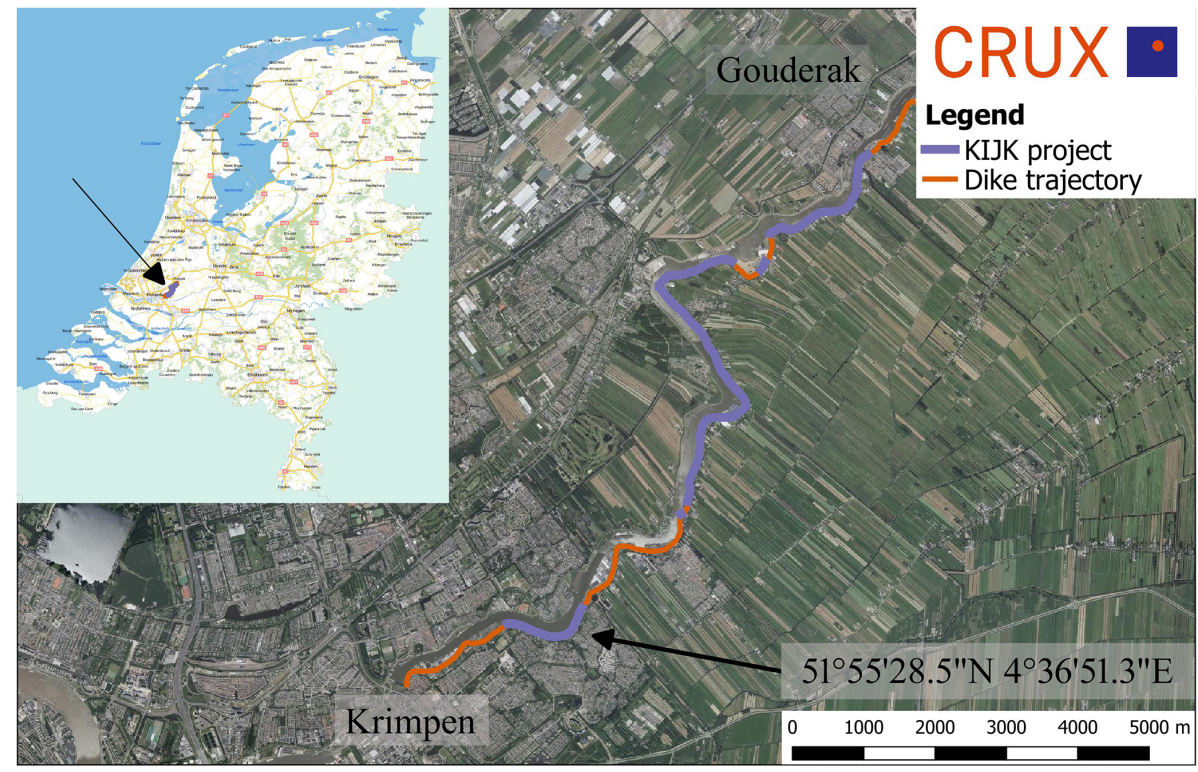

Figure 1. Location of the KIJK project (aerial photo 2016; (C) Nationaal georegister).

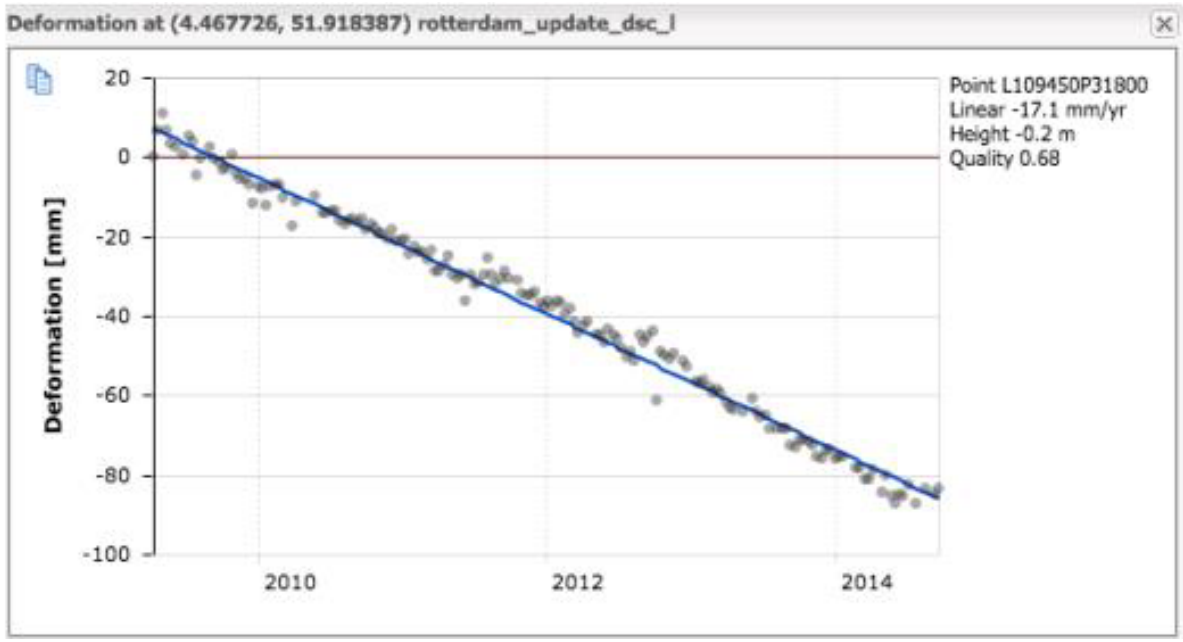

Figure 2. Example of InSAR measurements.

\section{Availability municipal archives}

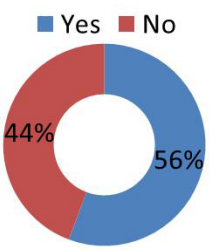

\section{Availability InSAR} measurements

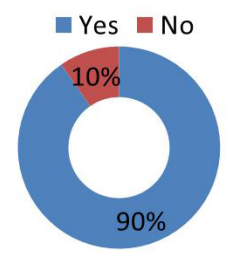

Figure 3. Data availability.

of AHN3 (Current Height Elevation, third data set, AHN, 2019) and BAG (Basic administration Addresses and Buildings, 2019) is used in this process. Also, multiple municipal archives are searched for drawings of all buildings. This data is used to establish a correlation to determine the characteristics of the buildings that lack archive data. The objective is to create a complete database of the foundation properties of all the buildings.

The additional land subsidence due to the levee strengthening is calculated for different designs using the FEM (Finite Element Method) code PLAXIS. The established differential horizontal and vertical soil displacements are combined with the foundation type to assess the risk of damage. The risk of damage can be determined using the limiting ten- 


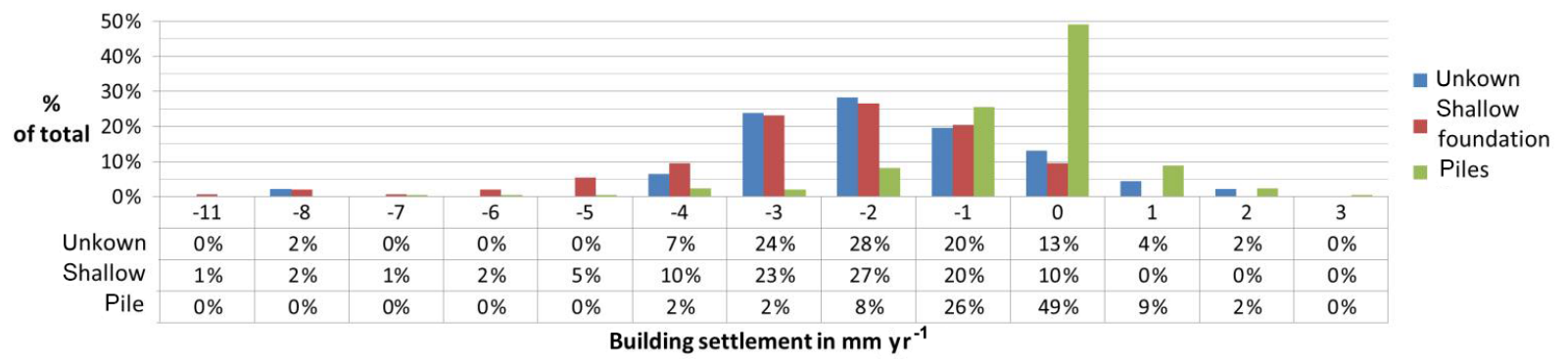

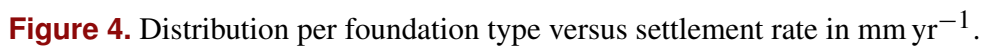

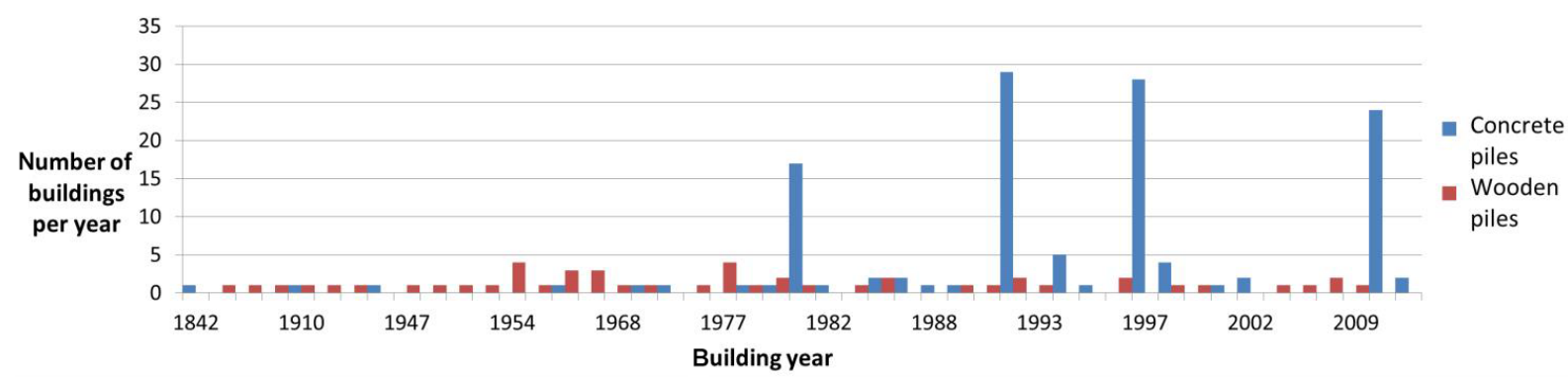

Figure 5. Distribution of pile materials over time.
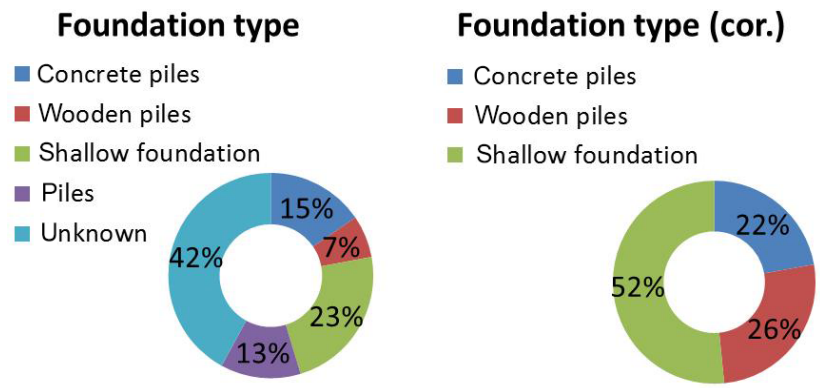

Figure 6. Foundation types before and after data analysis.

sile strain method (Netzel, 2009). The objective is to minimize this risk of damage by optimising the designs.

\section{Analysis of InSAR data and other sources}

\subsection{InSAR (Interferometric Synthetic Aperture Radar)}

The InSAR data consists of a large number of height measurements for an object, i.e. the building. Every eleven days the satellites pass the project area and scan the surface of the earth, for this project three year of data has been used. The measurements do not contain an accurate measurement of the level of the location but do give an accurate difference of height over time. An example on an individual surface point is given in Fig. 2. InSAR data is generally available on reflective points on the surface of the earth, such as roads or buildings. The location of the buildings is relatively accurately known using the BAG data (BAG, 2019). The height of

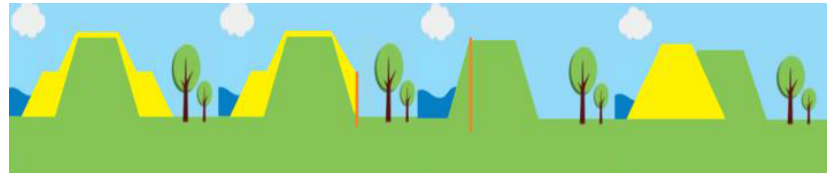

Figure 7. Types of levee strengthening, left to right, 1 to 4 .

a building and the surrounding ground level is known using the AHN3 data set (AHN, 2019). Both data sets have been used to filter out the InSAR data points that are on a building. All measurement points that are more than $3 \mathrm{~m}$ above the ground level, based on AHN3, and within $2 \mathrm{~m}$ of a building, using BAG, are linked to that building. With this procedure one or multiple measurement points are found for $90 \%$ of the buildings in the project area (see Fig. 3).

\subsection{BAG}

The building administration, BAG, does not only give the accurate location of the buildings, but also contains a lot of registered municipal data. Some basic properties of all buildings are included, like the address, the function, building year and special properties such as a listed building or "monumental status".

\subsection{City archives}

The local city archives proved to be well organised but far from complete. For $56 \%$ of all buildings valuable information was available, ranging from drawings to calcula- 


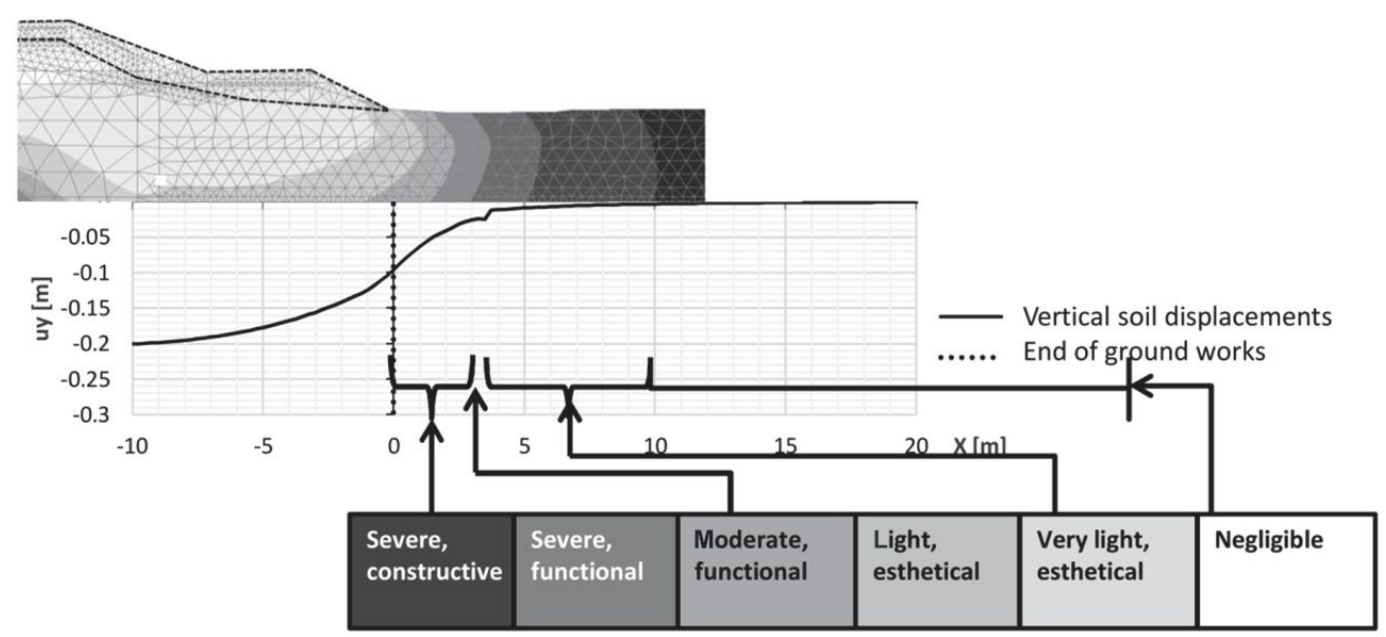

Figure 8. Categorized risk due to dike strengthening with groundworks for buildings with a shallow foundation.

tions, which resulted in information on construction materials, foundation type, material and depth, reconstructions and miscellaneous.

\subsection{Visual inspection}

Visual inspections have been performed to get a better understanding of the area and the structural status of the buildings. A photograph is made of every building from public terrain to be included in the database

\section{Combining data}

The objective is to obtain building characteristics for the remaining $44 \%$ of the buildings for which no archive information was available. The building settlement rate is known for $90 \%$ of the buildings, while for $42 \%$ of all buildings drawings are available. For $52 \%$ of those buildings with drawings, the foundation type is given in one of the drawings. A distribution of the settlement rate versus foundation type is given in Fig. 4. The foundation type is categorized in shallow foundations, pile foundations or unknown. From the graph it can be concluded that $72 \%$ of all buildings that have a shallow foundation settle at least $2 \mathrm{~mm} \mathrm{yr}^{-1}$, while only $12 \%$ of buildings founded on piles settle at that rate. $88 \%$ of all buildings on piles settle $1 \mathrm{~mm} \mathrm{yr}^{-1}$ or less.

The data shows that there is no $100 \%$ correlation between the building settlement rate and the foundation type. An important factor could be the technical state of the foundation as wooden piles deteriorate in time and possible other factors, such as reinforcements, which could have had impact on the building during the period of measurements. The distinction is made to consider all buildings that settle more than $2 \mathrm{~mm} \mathrm{yr}^{-1}$ to have a shallow foundation. All buildings that settle less than $1 \mathrm{~mm} \mathrm{yr}^{-1}$ are considered to be founded on piles. This is a safe assumption in the design process.

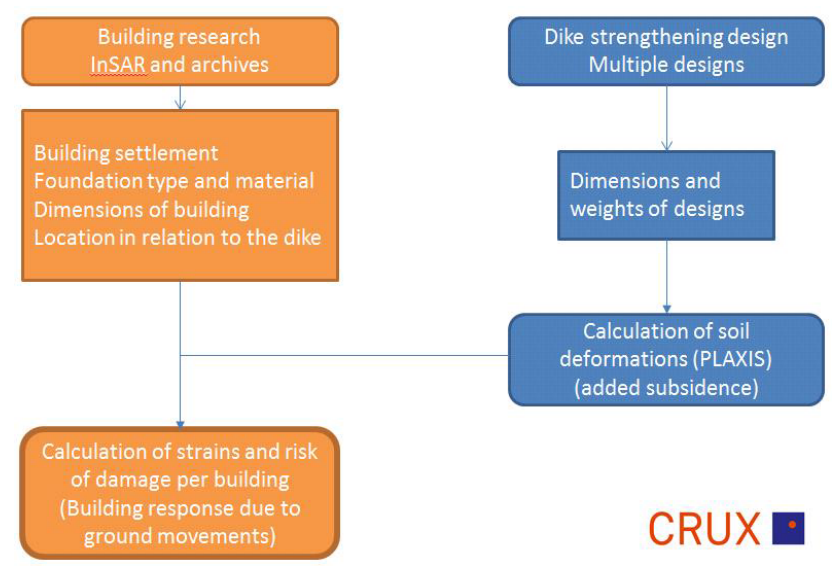

Figure 9. Flow chart of the performed analyses.

The data shows that it was not possible to determine the pile type only based on the building settlement rate. But there is a correlation between the pile type and building year. Wooden piles have been used in the past but have been replaced with concrete piles in the last couple of decades. Using the graph in Fig. 5 it can be stated that most buildings build after 1980 are built on concrete piles.

Using the two derived correlations a foundation type and material can be defined for all buildings where the archives lack information (Fig. 6). This is important input for the determination of the risk of building damage.

\section{Ground deformation caused by construction works}

There are multiple methods for strengthening a levee, see Fig. 7. Clay can be added to the crest and the slopes to increase height and stability (1). To narrow the strengthened 
Table 1. Results, minimal distances to levee strengthening

\begin{tabular}{|c|c|c|c|c|c|c|c|c|}
\hline \multirow{3}{*}{$\begin{array}{l}\text { Location } \\
\text { in relation } \\
\text { to dike }\end{array}$} & \multirow{3}{*}{$\begin{array}{l}\text { Foundation } \\
\text { type }\end{array}$} & \multirow{3}{*}{$\begin{array}{l}\text { Design solution } \\
\text { (Conform } \\
\text { Fig. 7) }\end{array}$} & \multicolumn{6}{|c|}{ Risk of damage } \\
\hline & & & $\begin{array}{r}\text { Severe, } \\
\text { constructive }\end{array}$ & $\begin{array}{r}\text { Severe, } \\
\text { functional }\end{array}$ & $\begin{array}{l}\text { Moderate, } \\
\text { functional }\end{array}$ & $\begin{array}{r}\text { Light, } \\
\text { esthetical }\end{array}$ & $\begin{array}{l}\text { Very light, } \\
\text { esthetical }\end{array}$ & Negligible \\
\hline & & & & ance betwee & building an & works till ( & & Distance from (m) \\
\hline \multirow{9}{*}{ 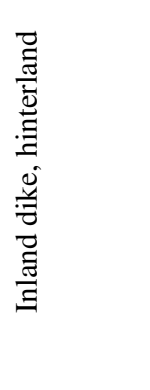 } & Shallow & 1 & 3.0 & - & 3.5 & - & 9.5 & 9.5 \\
\hline & foundation & 2 & - & - & - & - & 1.0 & 1.0 \\
\hline & & 4 & 6.0 & - & 8.5 & - & - & 8.5 \\
\hline & Wooden & 1 & 9.0 & - & - & - & - & 9.0 \\
\hline & piles & 2 & 18.5 & - & - & - & - & 18.5 \\
\hline & & 4 & 22.5 & - & - & - & - & 2.5 \\
\hline & Concrete & 1 & - & - & - & - & - & - \\
\hline & piles & 2 & - & - & - & - & - & - \\
\hline & & 4 & - & - & - & - & - & - \\
\hline \multirow{6}{*}{ 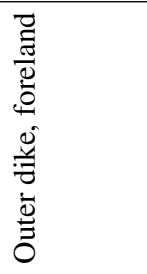 } & Shallow & 1 & 12.0 & - & 13.0 & 17.0 & 18.0 & 18.0 \\
\hline & foundation & 2 & 10.0 & - & 13.0 & 15.0 & 16.0 & 16.0 \\
\hline & Wooden & 1 & 13.5 & - & - & - & - & 13.5 \\
\hline & piles & 2 & 12.0 & - & - & - & - & 12.0 \\
\hline & Concrete & 1 & 6.5 & - & - & - & - & 6.5 \\
\hline & piles & 2 & 6.0 & - & - & - & - & 6.0 \\
\hline
\end{tabular}

levee profile retaining walls can be installed at one or both slopes to increase stability (2). Also, a single retaining wall can be installed in the crest to ensure both stability and height (3). Or the whole levee can be moved inland or outland when sufficient space is available (4).

When clay is placed on the levee, the underlying peat and clay layers are loaded, leading to additional subsidence. The additional subsidence is different depending on design and location, due to the changing profile of the levee and the soil heterogeneity. It is impossible to calculate the additional land subsidence for each individual building and all the different design options. So, the soil displacements are not calculated for each location or building, but for five representative locations.

The soil displacements have been calculated using PLAXIS for five locations and for all different designs. In these models the buildings have not been modelled. When determining the risk of damage, the soil or greenfield displacements will be imposed on the different buildings, based on their foundation. An example is given in Fig. 8 for levee strengthening with only clay on both slopes of the levee. On the right side is the hinterland, were buildings are located. It shows the vertical displacements, which decrease with the distance to the added load. Table 1 shows the risk of damage for different designs and buildings in relation to the distance to the levee strenthening for the project KIJK.

\section{Assessing the risk of damage}

Based on the method developed by Netzel (2009) the greenfield displacements are imposed on the building using the limiting tensile strain method.

The amount of deformation imposed on the building depends on the foundation type. The displacement of a shallow foundation is considered to be equal to the greenfield displacements. For pile foundations only a part of the greenfield deformation will act on the building itself. The dragdown force of the settling soil will impose a load on the pile (negative skin friction) which results in a settlement of the pile which is less than the greenfield settlement. For wooden and concrete piles respectively $20 \%$ and $7 \%$ of the vertical displacement will act on the building itself. A safe upper limit for the horizontal displacement factor is $50 \%$ of the greenfield displacements. The percentages that have been used are based on literature and experience by CRUX.

The risk of damage is categorized using the BREclassification using five levels of damage, ranging from structural damage (1) to light esthetical damage (5) or a negligible risk of damage. This assessment has been done for 10 different buildings along the levee for all four alternatives. The distance between the buildings and the levee axis, e.g. the distance to the levee strengthening alternatives, is known in the database. This is combined with geometrical data (distance between levee, construction method and building) to assess risk of damage, as illustrated in Fig. 9. The graph shows that 
the vertical displacements decrease with an increasing distance to the levee. It shows that, for this case, buildings, with a shallow foundation, within $3 \mathrm{~m}$ to the toe of the new levee will suffer severe, constructive damage because of the soil displacements, while for all buildings from $10 \mathrm{~m}$ from the toe the damage will be negligible.

\section{Conclusions}

The InSAR measurements proved to be able to determine the building settlement for almost all buildings of the KIJK project. Combining the building settlement with other data sources it is possible to estimate the foundation type of a building. Although this is not $100 \%$ accurate, it gives in combination with safe assumptions a good indication in the preliminary design phase of the project.

The foundation type, combined with distance to the construction site and settlement prediction resulted in a prediction of the risk of damage for each building and levee design. In these calculations the additional building settlement is calculated for all the approximately 1000 buildings along the $10 \mathrm{~km}$ of levee and all 4 design options. This risk assessment has been an important parameter in the Multi Criteria Analysis to establish the most favourable design alternative for the KIJK levee strengthening project.

Data availability. The request for the provision of the data, as owned by HHSK, will be treated by HHSK based on the purpose of the request (see https://www.schielandendekrimpenerwaard.nl, last access: 1 March 2020). To determine whether the request can be met, the purpose must be specified with the request.
Author contributions. MK and RRB made the analysis of the data. JKH and JWZ gave advice during the analysis. MW was representative of the HHSK for the project. RRB prepared the manuscript with contribution from all co-authors.

Competing interests. The authors declare that they have no conflict of interest.

Special issue statement. This article is part of the special issue "TISOLS: the Tenth International Symposium On Land Subsidence - living with subsidence". It is a result of the Tenth International Symposium on Land Subsidence, Delft, the Netherlands, 17-21 May 2021.

Acknowledgements. The work presented in this paper is part of the KIJK levee strengthening project in the Netherlands. The authors would like to thank their partners from IB-KIJK, BWZ Ingenieurs, Greenrivers and Infram and the anonymous reviewers for their comments to improve the quality of the paper.

\section{References}

AHN: https://www.ahn.nl/ahn-viewer, last access: July 2019.

Basisregistratie Adressen en Gebouwen (BAG): https://bagviewer. kadaster.nl, last access: July 2019.

Netzel, H. D.: Building response due to ground movements, 2009

IB KIJK Schademonitoring - Schadepredicties kansrijke alternatieven, 18 May 2018.

IB KIJK Schade monitoring - belendingenonderzoek, 31 March 2017.

SkyGeo: InSAR measurements, 2017. 